\title{
Population connectivity among geographic variants within the Lutjanidae (Pisces) of the Mexican Pacific coast through fish scale shape recognition
}

\author{
ANA L. IBÁÑEZ ${ }^{1}$, ELAINE ESPINO-BARR ${ }^{2}$ and MANUEL GALLARDO-CABELLO ${ }^{3}$ \\ ${ }^{1}$ Universidad Autónoma Metropolitana-Iztapalapa, Departamento de Hidrobiología, Av. San Rafael Atlixco 186, Col. \\ Vicentina, México, D.F. 09340 México. E-mail: ana@xanum.uam.mx \\ ${ }^{2}$ Instituto Nacional de la Pesca (INAPESCA), Centro Regional de Investigación Pesquera (CRIP-Manzanillo), \\ Playa Ventanas s/n, Manzanillo, Colima. C.P. 28200. \\ ${ }^{3}$ Instituto de Ciencias del Mar y Limnología, Universidad Nacional Autónoma de México, Av. Ciudad Universitaria 3000, \\ Col. Copilco, México, D.F. C.P. 04360.
}

SUMMARY: Fish scale shape was used to identify geographic variants among Lutjanidae (Lutjanus argentiventris, $L$. guttatus and L. peru). Specimens were collected from three different geographic areas, north to south of the tropical Pacific coast of Mexico: Puerto Vallarta (PV), Manzanillo (MA) and Caleta de Campos (CC). Configuration of landmark coordinates of fish scales were scaled, translated and rotated using generalized procrustes analysis, followed by principal components analysis of resulting shape coordinates. Principal component scores were submitted to cross-validated discriminant analysis to determine the efficacy of scale landmarks for discrimination by geographic variants. This was done with shape and form (shape plus size). PV and MA were recognized as one population different from the CC sampling area. Using only shape (without size), identification rates predicted geographic variant membership much better than chance $(91.3 \%, 70.6 \%$ and $85.4 \%$ for $L$. argentiventris, L. guttatus and $L$. peru, respectively), and taking size into account, classification is somewhat improved $(90.6 \%, 80.1 \%$ and $87.5 \%$ for L. argentiventris, L. guttatus and L. peru, respectively). Consistency of the two populations for the three species shows non-fortuitous events. Population discrimination confirmed previous genetic studies that show a zoogeographic barrier between the North Equatorial Current and the California Current. The method is nondestructive, fast and less expensive than genetic analysis, thus allowing screening of many individuals for traceability of fish.

Keywords: scale shape, population discrimination, fish traceability, Lutjanidae, Mexican Pacific, geometric morphometrics.

RESUMEN: Conectividad poblacional entre variantes geográficas de Lutjanidae (Pisces) en las costas del Pacífico MEXICANO A TRAVÉS DEL RECONOCIMIENTO DE LA FORMA DE LAS ESCAMAS. - La forma de las escamas se usó para identificar variantes geográficas de tres especies de Lutjanidos (Lutjanus argentiventris, L. guttatus and L. peru). Los especímenes se colectaron en tres diferentes áreas geográficas en la zona costera del Pacífico mexicano, de norte a sur: Puerto Vallarta (PV), Manzanillo (MA) and Caleta de Campos (CC). La configuración de coordenadas referenciadas de las escamas fueron escaladas, trasladadas y rotadas usando el análisis generalizado Procrustes, las coordenadas resultantes fueron sometidas a análisis de componentes principales mientras que los scores de los componentes se sometieron a validación cruzada con el análisis discriminante con el objeto de determinar la eficacia de las coordenadas referenciadas en la discriminación de las variantes geográficas. Esto se realizó considerando la forma y la talla. Los resultados mostraron que PV y MA se reconocieron como una sola población diferente de los ejemplares del área de CC. Usando solamente la forma de la escama (sin considerar la talla) las tasas de identificación entre las variantes geográficas fueron mejores que al azar $(91.3,70.6$ y $85.4 \%$ para $L$. argentiventris, L. guttatus y L. peru, respectivamente) y agregando la talla la clasificación mejora un tanto (90.6, 80.1 y 87.5\% para $L$. argentiventris, $L$. guttatus y L. peru, respectivamente). La consistencia en los resultados de dos poblaciones para las tres especies de lutjánidos muestra que este resultado no es fortuito. La discriminación de estas dos poblaciones confirma previos estudios genéticos que muestran una barrera geográfica entre la corriente Nor-ecuatorial y la corriente de California. El método no es destructivo es rápido y mucho más económico que un análisis genético además de permitir la revisión de una muestra amplia de individuos para la trazabilidad de peces.

Palabras clave: forma de escamas, discriminación de poblaciones, trazabilidad de peces, Lutjanidae, Pacífico mexicano, morfometría geométrica. 


\section{INTRODUCTION}

Population identification is important in fisheries management, in which individual specimens have to be correctly identified to population in order to investigate biological traits such as growth, mortality, fecundity, trophic relationships, parasite relationships, and historical and paleontological events (Sparre and Venema 1995). According to Begg and Waldman (1999), the stock concept describes the characteristics of the units assumed to be homogeneous for particular management purposes. In other words, the signal from among-stock variation must exceed the noise of within-stock variation (Waldman 1999). Fisheries management normally aims to reach maximum or sustainable production from fish stocks frequently defined on the basis of the same vital rate parameters that are used for productivity calculations (Begg and Waldman 1999), ignoring such information can lead to ineffective fisheries management. From the point of view of coastal management, the efficient transfer of individuals among local populations is one of the essential forms of connectivity. Connectivity is the quantity of biological material (larvae, recruits, juveniles or adults) exchanged between populations of a particular species along its distribution range (Palumbi 2003). Since it can include exchange of offspring between populations through larval dispersal, recruitment of juveniles and survival of these juveniles to reproductive age, and any large-scale movement of juveniles and adults between locations, connectivity can influence population demographics and dynamics.

Morphometrics analysis has been valuable in species discrimination (Ibáñez and Lleonart 1996), in size shape variation (Lombarte and Lleonart 1993) and in the definition of population in fisheries science and management. Fourier analysis of fish scales has been used to discriminate populations (e.g. Jarvis et al. 1978, Richards and Esteves 1997). To improve discrimination, Watkinson and Gillis (2005) used wavelet analysis as an alternative to Fourier analysis. Different methods of shape analysis based on landmark data and geometric morphometric methods (GMM) have been developed in the last few decades since use biological equivalences between structures or 'homologous' landmarks and resulting metrics found in biology.

Recently, Ibáñez et al. (2007) applied GMM to scales in order to identify genera, species and local populations among the Mugilidae. Garduño-Paz et al. (2010) also used fish-scale morphometrics and were able to discriminate between sympatric phenotypes of the Arctic charr (Salvelinus alpinus). The use of scale shape seems valuable in population discrimination and could become an important and practical fisheries management tool. The use of otoliths for this purpose is well recognized, and while their use requires more labour and expensive equipment, it is clearly effective (Farias et al. 2009, Hong-Yi et al. 2010), However, it is an invasive method.
According to Allen (1985), the family Lutjanidae includes 17 genera and 103 species that live in coastal waters in tropical and subtropical regions. Snappers are marine species that can swim into lagoons and estuaries to feed on crustaceans and fish. These species constitute one of the most important coastal fisheries in Mexico due to their catch volume, which exceeds 11560 metric tons annually. Most of the catch takes place in the Pacific coast $7100 \mathrm{mt}$ in 2009. Catch volumes of Lutjanidae species during 2009 in the areas was: PV, $1188 \mathrm{mt}, \mathrm{MA}, 109 \mathrm{mt}$ and in CC, $382 \mathrm{mt}$ (SAGARPA 2010). Accurate assessments of the status of fish populations require efficient and cost effective monitoring methods. This is particularly important for populations in developing countries. In this sense the aim of this study was to evaluate whether landmark based, geometric morphometric approach to describe fish scale morphology is useful in discriminating among geographic variants. The null hypothesis states that differences in fish scale morphology between geographic variants in three species of Lutjanidae: $\mathrm{Lu}$ tjanus argentiventris (Peters 1869), L. guttatus (Steindachner 1869) and L. peru (Nichols and Murphy 1922) are insufficient to identify geographic variants.

\section{MATERIALS AND METHODS}

\section{Fish scale collection/age and size range of fishes}

Scales of $L$. argentiventris, $L$. guttatus and $L$. peru were collected from specimens caught in the commercial fishery in Puerto Vallarta, Jalisco (PV); Manzanillo, Colima (MA) and Caleta de Campos, Michoacán (CC) in the Pacific coast of Mexico between August 2005 and May 2008 (Fig. 1 and Table 1). At each sampling site gillnets of $3.5,4$ and 4.5 inches mesh size were used.

Fish were measured to the nearest millimetre and scales were removed from the left side of the body, in the protected area under the pectoral fin where the dorsal fin starts. This area was selected because the scales there were found to be the best for identification purposes (Ibáñez et al. 2009). Scales were stored dry in paper envelopes. In the laboratory scales were cleaned with soft soap and tap water with the help of a small toothbrush, then rinsed, dried and fixed between two glass slides; they were examined using a microfiche projector. A digital image was taken from the flat screen of the projector. One scale per fish was used for the analysis (Table 1) with the purpose of attempting to evaluate a fast population discrimination methodology that does not require repetitive sampling of individuals. Significant size differences were found among geographic variants for the three species $(P<0.05)$. Regenerated scales were discarded from the analysis because possible shape alteration due to the regeneration process was not analysed. Regenerated scales were identified by a diffused focus and an abnormal pattern of circulus formation. The morphology of the regen- 
TABLE 1. - Size of sample and site of collection of fish scales: Lar = Lutjanus argentiventris; Lgu = L. guttatus; Lpe = L. peru .

\begin{tabular}{|c|c|c|c|c|c|c|}
\hline Species & Site of collection & Group code & $\begin{array}{l}\text { Number } \\
\text { of fish }\end{array}$ & $\begin{array}{l}\text { Total length } \\
\text { mean } \pm \text { std }\end{array}$ & $\begin{array}{l}\text { Total length } \\
\text { range }\end{array}$ & $\begin{array}{l}\text { Sample collection } \\
\text { period }\end{array}$ \\
\hline Lutjanus argentiventris (Lar) & $\begin{array}{l}\text { Puerto Vallarta, Jal. (PV) } \\
\text { Manzanillo, Col. (MA) } \\
\text { Caleta de Campos, Mich. (CC) }\end{array}$ & $\begin{array}{l}\text { Lar-PV } \\
\text { Lar-MA } \\
\text { Lar-CC }\end{array}$ & $\begin{array}{l}45 \\
52 \\
41\end{array}$ & $\begin{array}{l}31.6 \pm 6.1 \\
35.6 \pm 7.3 \\
43.9 \pm 9.7\end{array}$ & $\begin{array}{l}19.4-50.0 \\
24.0-59.0 \\
18.5-54.5\end{array}$ & $\begin{array}{l}\text { Sep2007-May2008 } \\
\text { Nov2007-May2008 } \\
\text { Aug2005-Jun2006 }\end{array}$ \\
\hline Lutjanus guttatus (Lgu) & $\begin{array}{l}\text { Puerto Vallarta, Jal. (PV) } \\
\text { Manzanillo, Col. (MA) } \\
\text { Caleta de Campos, Mich. (CC) }\end{array}$ & $\begin{array}{l}L g u-\mathrm{PV} \\
L g u-\mathrm{MA} \\
\text { Lgu-CC }\end{array}$ & $\begin{array}{l}47 \\
50 \\
39\end{array}$ & $\begin{array}{l}28.9 \pm 2.5 \\
25.0 \pm 1.4 \\
26.3 \pm 4.9\end{array}$ & $\begin{array}{l}23.0-34.0 \\
22.0-28.0 \\
17.3-38.0\end{array}$ & $\begin{array}{c}\text { Sep2007-May2008 } \\
\text { Oct2007 } \\
\text { Aug2005-Jun2006 }\end{array}$ \\
\hline Lutjanus peru (Lpe) & $\begin{array}{l}\text { Puerto Vallarta, Jal. (PV) } \\
\text { Manzanillo, Col. (MA) } \\
\text { Caleta de Campos, Mich. (CC) }\end{array}$ & $\begin{array}{l}\text { Lpe-PV } \\
\text { Lpe-MA } \\
\text { Lpe-CC }\end{array}$ & $\begin{array}{l}53 \\
50 \\
41\end{array}$ & $\begin{array}{l}27.5 \pm 2.0 \\
24.5 \pm 2.6 \\
25.0 \pm 6.2\end{array}$ & $\begin{array}{l}21.2-33.0 \\
19.6-29.5 \\
18.0-33.0\end{array}$ & $\begin{array}{c}\text { Sep-Nov2007 } \\
\text { Oct2007 } \\
\text { Aug2005-Jun2006 }\end{array}$ \\
\hline
\end{tabular}

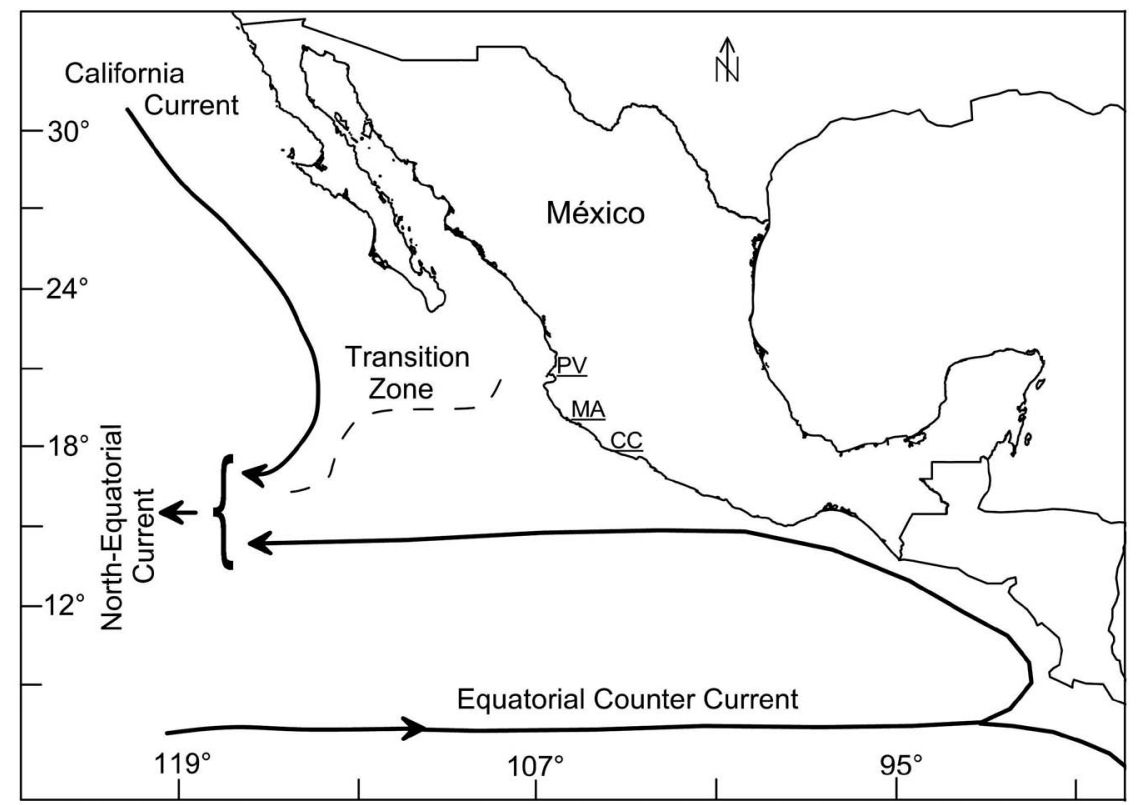

FIg. 1. - Sampling locations in the Tropical Pacific of Mexico: Puerto Vallarta, Jalisco (PV), Manzanillo, Colima (MA) and Caleta de Campos, Michoacán (CC). Oceanic currents with influence in Mexican seas (from Fernández et al. 1992).

erated focus is the consequence of the rapid development of scale replacement through activation of a large number of scale-pocket lining cells. This process may possibly modified scale shape.

\section{Morphometrics}

Preliminary visual assessment was used to identify potential landmarks on the scales. The landmarks selected were positioned on key features of the scale that were common to all scales of the species or of the geographic variants examined. For Lutjanidae fish scales the following landmarks were considered appropriate (Fig. 2) according to Ibáñez et al. (2007): landmarks 1 and 3 are the boundary between the anterior area with circuli and the posterior area covered by cteni (spinelike ornamentations), landmark 4 is in the centre of the anterior edge of the scale, landmark 2 is the focus of the scale and landmark 5 is positioned at the tip of the posterior portion of the scale.

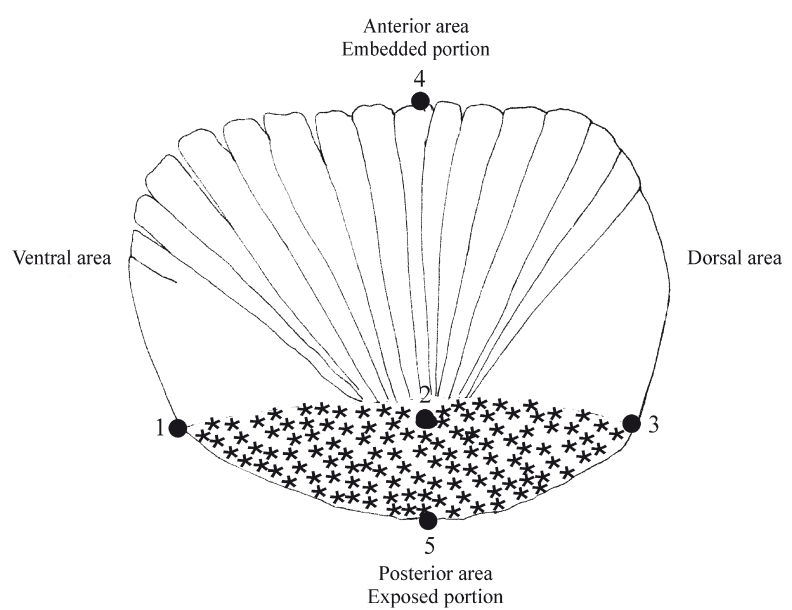

FIG. 2. - Location of landmark on scales of Lutjanid fishes used in analysis. 
The configurations of landmark coordinates were scaled, translated and rotated using generalized procrustes analysis (GPA). They were then submitted to tangent projection (Dryden and Mardia 1993) and subsequently the relative warps which are the principal components (PC) of Procrustes shape coordinates were obtained (Mitteroecker and Gunz, 2009, Dryden and Mardia 1993, Kent 1994). The aim was to study the potential differences in shape needed for the classification of unknown populations by species, so the scores of specimens on all principal components were submitted to canonical discriminant analysis to compute generalized Mahalanobis distances to discriminate functions and to assess the efficacy in their classification. Crossvalidated discriminant analysis was used to assess and compare the efficacy of shape and form data (shape plus size because significant size differences were found) in classification by geographic variants and species.

A post-hoc univariate analysis of variance to test whether there were significant differences between the discriminate scores (Ds) of the three groups (PV, MA and CC) were carried out. Therefore, in order to obtain variance homoscedasticity, only the first Ds were used in the analysis because they contain most of the variance.

Aspects of shape variability represented by the discriminant functions were estimated by multivariate regression of PC scores on discriminant function scores. The PC scores predicted by the extremes of each discriminant function were then used to recreate the shape of landmark configurations with these particular scores by adding their products to the mean tangent coordinates and the eigenvectors for the PCs before projecting back from the tangent to the configuration space (O'Higgins et al. 2001). Finally, the differences in shape between the mean and the shapes shown by the extremes of discriminant functions of interest were visualized using transformation grids computed with thin plate splines (TPS) (Bookstein 1989, Marcus et al. 1996, Dryden and Mardia 1998).

Sequential analyses were carried out to assess the extent to which scale shape and form differences (shape plus size), as described by landmarks, allowed species identification by geographic variants.

Landmarks were obtained using TPSDig2 (Rohlf 2006). Morphologika2 (O’Higgins and Jones 2007) was used for geometric morphometric analyses. Also, the differences in shape between the mean and the shapes represented by the extremes of PCs of interest were visualized using transformation grids (Bookstein 1989; Marcus et al. 1996; Dryden and Mardia 1998) computed with Morphologika2 (O'Higgins and Jones 2007). The statistical analyses were performed using the Statistical Package for the Social Sciences (SPSS v.13.0).

\section{RESULTS}

The first canonical discriminant function for fish scale shape of 138 individuals of L. argentiventris classified by geographic variants accounted for $97.4 \%$
TABle 2. - Classification results ${ }^{\mathrm{a}, \mathrm{b}, \mathrm{c}}$ of discriminant analysis of fish scale shape for the three geographic variants (PV, Puerto Vallarta; MA, Manzanillo; and CC, Caleta de Campos). Total classification success for cross-validated predicted geographic variant membership.

\begin{tabular}{|c|c|c|c|c|}
\hline & Pre & Group & bership & \\
\hline & PV & MA & $\mathrm{CC}$ & Total \\
\hline L. $a r$ & & & & \\
\hline PV & 51.1 & 46.7 & 2.2 & 100.0 \\
\hline MA & 44.2 & 48.1 & 7.7 & 100.0 \\
\hline $\mathrm{CC}$ & 9.8 & 7.3 & 82.9 & 100.0 \\
\hline L. $g u$ & & & & \\
\hline PV & 40.4 & 40.4 & 19.1 & 100.0 \\
\hline MA & 34.0 & 44.0 & 22.0 & 100.0 \\
\hline $\mathrm{CC}$ & 23.1 & 15.4 & 61.5 & 100.0 \\
\hline L. pe & & & & \\
\hline PV & 58.5 & 35.8 & 5.7 & 100.0 \\
\hline MA & 32.0 & 62.0 & 6.0 & 100.0 \\
\hline $\mathrm{CC}$ & 9.8 & 17.1 & 73.2 & 100.0 \\
\hline
\end{tabular}

a $59.4 \%$ of cross-validated grouped cases correctly classified.

b $47.8 \%$ of cross-validated grouped cases correctly classified.

${ }^{c} 63.9 \%$ of cross-validated grouped cases correctly classified.

of the total while the second accounted for $2.6 \%$ (Wilks' lambda=0.388, $P<0.0001$ ). The discriminant analysis correctly classified $67.4 \%$ of the fish scales to geographic variants, while the cross-validated analysis correctly classified $59.4 \%$ of the fish scales (Table 2). The best classification rate, $82.9 \%$, was for CC, compared with $48.1 \%$ and $51.1 \%$, respectively, for MA and PV; most misclassifications occurred between MA and PV (Table 2).

Two groups were defined in the plot of the first two discriminant functions from the analysis of the 138 individuals. Centroids and specimens of PV, MA and $\mathrm{CC}$ were separated principally on the first discriminant function axis (Fig. 3A).

The first discriminant function from the analysis of 136 fish scales of L. guttatus specimens accounted for $85.1 \%$ of the total, while the second accounted for $14.9 \%$ (Wilks' lambda=0.705, $P<0.0001$ ). The discriminant analysis correctly classified $54.4 \%$ of the original grouped cases; while cross-validation resulted in $47.8 \%$ correct classification (Table 2). The best classification rate, $61.5 \%$, was for $\mathrm{CC}$, compared with $44.0 \%$ and $40.4 \%$, respectively, for MA and PV; most misclassifications occurred between MA and PV (Table 2). Specimens from CC were distinguished in the discriminant analysis by the first function (Fig. 3B).

The first canonical discriminant function of fish scale shape of 144 individuals of $L$. peru classified by geographic variants accounted for $86.3 \%$ of the total, while the second accounted for $13.7 \%$ (Wilks' lamb$\mathrm{da}=0.442, P<0.0001)$. The discriminant analysis correctly classified $69.4 \%$ of the fish scales to geographic variants, while the cross-validated analysis correctly classified $63.9 \%$ of the fish scales (Table 2). The best classification rate, $73.2 \%$, was for $\mathrm{CC}$, compared with $62.0 \%$ and $58.5 \%$, respectively, for MA and PV. Most misclassifications occurred between MA and PV (Ta- 

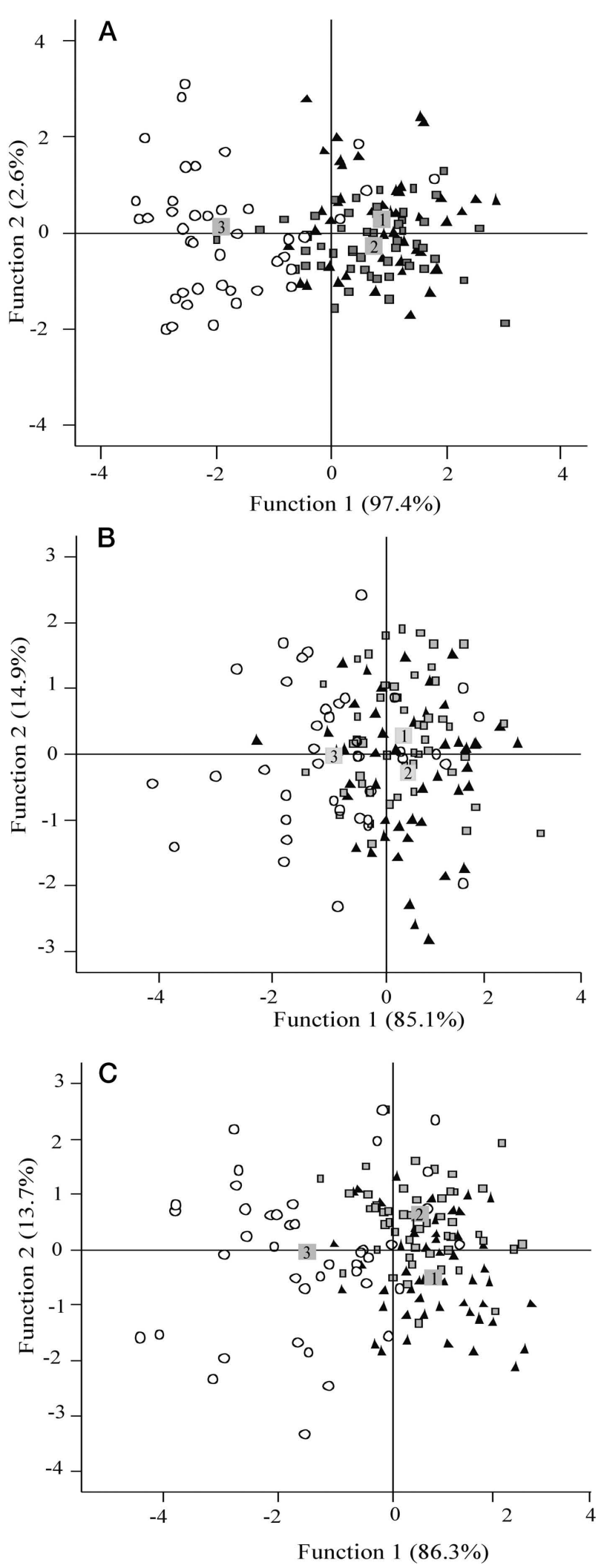

FIG. 3. - Scatter plot of the discriminant function scores from the analysis of geographic variants of Lutjanus argentiventris (A), $L$. guttatus (B) and L. peru (C). Black triangles, PV; Grey squares, MA; White circles, CC; Numbers over the grey squares, centroids.
TABLE 3. - Discriminant analysis of fish scale form of three geographic variants (PV, Puerto Vallarta; MA, Manzanillo; and CC, Caleta de Campos) of three lutjanid species. The percentage of the total variance explained by the first and second discriminant functions is shown. Total classification success for cross-validated predicted geographic variant membership.

\begin{tabular}{lccccc}
\hline Species & Wilks' $\lambda$ & $p$ & \multicolumn{2}{c}{$\begin{array}{c}\text { Discriminant } \\
\text { functions }\end{array}$} & Total \\
& & & $1^{\text {st }}$ & $2^{\text {nd }}$ & classification \\
results $(\%)$
\end{tabular}

ble 2). Two groups were defined in the plot of the first two discriminant functions from the analysis of the 144 individuals. Centroids and specimens of PV and MA were more separated on the second axis while CC and PV and MA were more separated by the first discriminant function (Fig. 3C).

Combined scale size and shape (Table 3) worked better than shape alone. The first canonical discriminant function for 138 individuals of $L$. argentiventris classified by geographic variants accounted for $97.4 \%$ of the total, while the second accounted for $2.6 \%$ (Wilks' lambda $=0.360, P<0.0001$ ). The discriminant analysis correctly classified $67.4 \%$ of the fish scales to geographic variants, while the cross-validated analysis correctly classified $61.6 \%$ of the fish scales. The first canonical discriminant function for 136 individuals of L. guttatus classified by geographic variants accounted for $89.0 \%$ of the total, while the second accounted for $11.0 \%$ (Wilks' lambda $=0.596, P<0.0001$ ). The discriminant analysis correctly classified $58.8 \%$ of the fish scales to geographic variants, while the cross-validated analysis correctly classified $52.9 \%$ of the fish scales. The first canonical discriminant function for 144 individuals of $L$. peru classified by geographic variants accounted for $88.5 \%$ of the total, while the second accounted for $11.5 \%$ (Wilks' lambda $=0.375, P<0.0001$ ). The discriminant analysis correctly classified $68.8 \%$ of the fish scales to geographic variants, while the crossvalidated analysis correctly classified $67.4 \%$ of the fish scales. The best classification rate was for CC and most misclassifications occurred between the MA and PV areas for the three species.

Using shape alone (without size), identification rates are much better than chance. When size is into account, cross-validation analysis classification is improved by $2.2 \%$ for $L$. argentiventris, by $5.1 \%$ for $L$. guttatus and by $3.5 \%$ for L. peru.

Since most of the misclassifications occurred between PV and MA, discriminant analyses were repeated labelling PV and MA as one group different from $\mathrm{CC}$ and later sequential analyses were carried out to determine the extent to which differences in scale shape and form (shape plus size), as described by landmarks, allow identification of local geographic variants by species.

Results of cross-validated classification from the analyses between PV+MA and CC for the L. argen- 
TABLE 4. - Classification results $\mathrm{s}^{\mathrm{a}, \mathrm{b}, \mathrm{c}}$ of discriminant analysis of fish scale shape for the two geographic variants (PV, Puerto Vallarta; MA, Manzanillo; and CC, Caleta de Campos). Total classification success for cross-validated predicted geographic variant membership.

\begin{tabular}{lccc}
\hline & \multicolumn{3}{c}{ Predicted Group Membership } \\
& PV+MA & CC & Total \\
\hline $\begin{array}{l}\text { L. } \text { argentiventris }^{\mathrm{a}} \\
\text { PV+MA }\end{array}$ & 92.8 & 7.2 & \\
CC & 12.2 & 87.8 & 100.0 \\
L. guttatus & & & \\
PV+MA & 72.2 & 27.8 & 100.0 \\
CC & 33.3 & 66.7 & 100.0 \\
L. peru & & & \\
PV+MA & 90.3 & 9.7 & 100.0 \\
CC & 26.8 & 73.2 & 100.0 \\
\hline
\end{tabular}

a $91.3 \%$ of cross-validated grouped cases correctly classified. b $70.6 \%$ of cross-validated grouped cases correctly classified.

c $85.4 \%$ of cross-validated grouped cases correctly classified.

tiventris geographic variants identified significant discrimination in all cases $(P<0.001)$. Cross-validated results for CC showed $87.8 \%$ correct overall classification and $92.8 \%$ for PV+MA (Wilks' lambda $=0.406$, $P<0.001)$. The cross-validation for the two combined areas correctly classified $91.3 \%$ of specimens overall (Table 4). The cross-validated classification results from the analysis between PV+MA and CC for the L. guttatus geographic variants identified significant
TABLE 5. - Discriminant analysis of scale form for the two geographic variants (PV, Puerto Vallarta; MA, Manzanillo; and CC, Caleta de Campos) by species. The percentage of classification results by geographic variant is shown. Classification results $(\%)$ for total cross-validated predicted geographic variant membership.

\begin{tabular}{lccccc}
\hline Species & Wilks' $\lambda$ & $p$ & \multicolumn{2}{c}{$\begin{array}{c}\text { Classification } \\
\text { results }(\%)\end{array}$} & $\begin{array}{c}\text { Total } \\
\text { classification } \\
\end{array}$ \\
& & & PV+MA & CC & results (\%) \\
\hline L. argentiventris & 0.377 & $<0.0001$ & 91.8 & 87.8 & 90.6 \\
L. guttatus & 0.649 & $<0.0001$ & 87.6 & 61.5 & 80.1 \\
L. peru & 0.450 & $<0.0001$ & 92.2 & 75.6 & 87.5 \\
\hline
\end{tabular}

discrimination in all cases $(P<0.001)$. The crossvalidated results for $\mathrm{CC}$ showed a $66.7 \%$ correct overall classification and $72.2 \%$ for PV+MA (Wilks' lambda=0.748, $P<0.001)$. The cross-validation for the two areas correctly classified $70.6 \%$ of specimens overall (Table 4). For the L. peru geographic variants the cross-validated results for $\mathrm{CC}$ showed a $73.2 \%$ correct overall classification and $90.3 \%$ for PV+MA (Wilks' lambda $=0.513, P<0.001$ ). The cross-validation for the two areas correctly classified $85.4 \%$ of specimens overall (Table 4).

Combined scale size and shape (Table 5) worked better than shape alone. The discriminant analysis for L. argentiventris correctly classified $91.3 \%$ of the fish scales to geographic variants, while the cross-validated analysis correctly classified $90.6 \%$ of the fish scales.
A
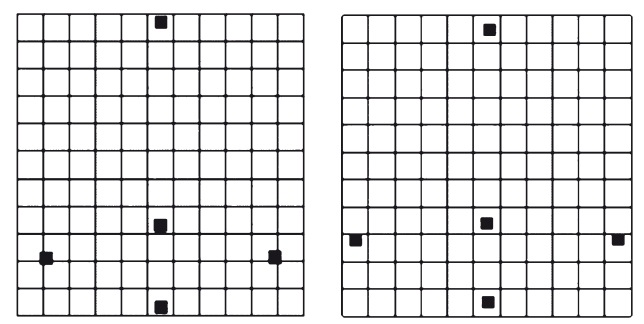

B

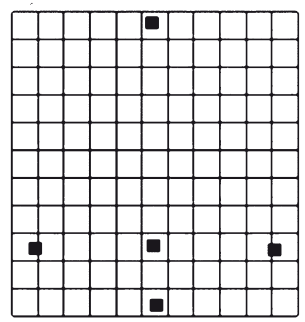

C

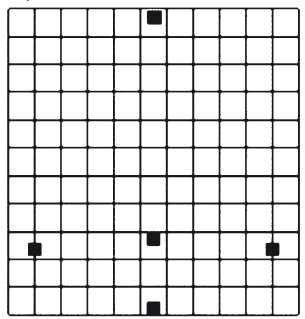

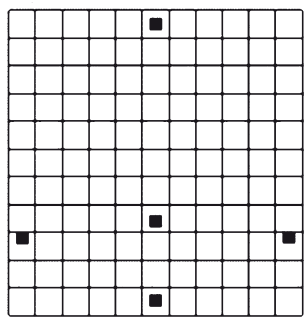
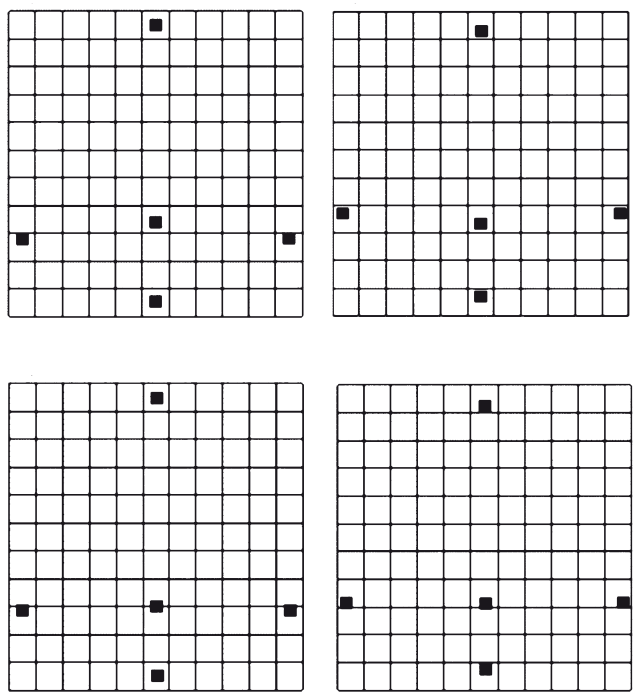

FIG. 4. - Shape variation along the first discriminant function of Figure 3 for Lutjanus argentiventris (A), Lutjanus guttatus (B) and Lutjanus peru (C) visualized using a transformation grid. From left to right each grid shows the predicted shape for discriminate function: left at -4.0 , centre at 0.0 and right at 4.0 . 
CC showed an $87.8 \%$ correct overall classification and $91.8 \%$ for $\mathrm{PV}+\mathrm{MA}$ (Wilks' lambda $=0.377, P<0.001$ ). The discriminant analysis for L. guttatus correctly classified $83.1 \%$ of the fish scales to geographic variants, while the cross-validated analysis correctly classified $80.1 \%$ of the fish scales. CC showed a $61.5 \%$ correct overall classification and $87.6 \%$ for PV+MA (Wilks' lambda $=0.649, P<0.001)$.

The discriminant analysis for $L$. peru correctly classified $88.2 \%$ of the fish scales to geographic variants, while the cross-validated analysis correctly classified $87.5 \%$ of the fish scales. CC showed a $75.6 \%$ correct overall classification and $92.2 \%$ for PV+MA (Wilks' lambda $=0.450, P<0.001)$.

Using only shape identification rates is much better than chance, and when size is taken into account cross-validation analysis classification is improved by $9.5 \%$ for L. guttatus and $2.1 \%$ for L. peru, whereas it is reduced by $0.7 \%$ for $L$. argentiventris.

The ANOVA between the Ds of the three groups (PV, MA and CC) for the three species was significant $(F>22.501, P<0.0001)$. Between pairs of geographic variants significant differences were found for the three species $(F>45.123, P<0.0001)$, with the exception of zones 1 and 2, where no differences were found in any species: L. argentiventris $(F=1.028, P=0.313)$; L. guttatus $(F=0.218, P=0.642)$ and $L$. peru $(F=2.311, P=0.132)$.

The shape variation represented by the first discriminant function of Figure 3 is visualized in Figure 4A, $\mathrm{B}$ and C, respectively, for L. argentiventris, L. guttatus and L. peru, using transformation grids. Figures on the left represent the scale shape at a discriminate score (DS) of -4.0 (more CC area specimens), figures at the centre the mean shape, and figures on the right (more $\mathrm{PV}$ and MA specimens) the scale shape at DS 4.0 for each species.

For the three species as DS 1 increases the exposed portion of the scale becomes wider (between landmarks 1 and 3; figures on the right) and the focus becomes more centralized within $L$. argentiventris specimens (Fig. 4A). On the other hand, as DS 1 decreases the scale becomes narrower between landmarks 1 and 3 and the focus tends to become more posterior, reducing the exposed area (figures on the left), in particular for L. guttatus and L. peru specimens (Fig. 4A,B).

\section{DISCUSSION}

Specimens of each species from the three geographic areas were separated as two local populations. Geographic variants Puerto Vallarta (PV) and Manzanillo (MA) did not show significant differences from each other while southern Caleta de Campos (CC) specimens were differentiated from the other two areas.

Our results give rise to an interesting assumption with respect to sea connectivity between local populations. PV is near the transition zone between the California Current and the North Equatorial Current (Fig.
1). Geographic localization of this transition area varies depending on the relative intensity of the currents and the dominant surface winds during six to eight months previously in the North Pacific (Fernández et al. 1992). In winter, when the California Current is more intense, this zone is located further south, and in summer, when the North Equatorial Countercurrent is more intense, it is located further north and the Mexican Pacific surface circulation is dominated mainly by the movement of the transition zone (Fernandez et al. 1992). FrancoGordo et al. (2002) found that during the period when advective processes associated with the California Current were active, fish larval assemblages were more homogeneous during the rest of the annual cycle. The predominance of each of these currents seems to leave a footprint in the growing process of fish scales that modifies the scale shape. Changes in fish scale shape have been recorded for juveniles of the cyprinid roach (Rutilus rutilus (L.)) reared on a fish farm in the UK when fish suffered compensatory growth owing to the type of holding facility movements, which are surrogates of food availability, density, temperature and other variables (Ibáñez et al. 2012). Environmental influences on morphology have led to the description of phenotypic populations characterized by phenotypic differences that may be fully environmentally induced (Swain and Foote 1999).

This shifting movement of the transition zone of hot and cold currents may be an important mixture factor that induces ecological or demographic connectivity between PV and MA, involving the exchange of individuals between populations and affecting population dynamics and demography on a generational or ecological time scale (Sale et al. 2010). Ecological connectivity plays an important role in the local population dynamics and metapopulations and in the structure, genetic diversity and resilience of exploited populations (Cowen et al. 2007).

High genetic diversity (mtDNA) has been reported for Scomberomorus sierra, Jordan and Starks 1895, and a highly significant divergence throughout the American Pacific (Domínguez-López et al. 2010). Two genetically different groups were found: one in the northern area (Sinaloa State around $22^{\circ} 30^{\prime} \mathrm{N}$ to $26^{\circ} 15^{\prime} \mathrm{N}$ ) and the second in the central area (Oaxaca and Chiapas State around $16^{\circ} 30^{\prime} N$ to $14^{\circ} 15^{\prime} N$ ). Similar genetic differences were found in species of the Lutjanidae family: L. guttatus and L. peru. (P. DíazJaime, pers. comm.). PV and MA are located in the transition zone between the California Current and the North Equatorial Current, whereas CC is located in a southern position.

According to Espino-Barr et al. (2010 and 2011), Gallardo-Cabello et al. (2010) and Sarabia-Méndez et al. (2010), the spawning periods of PV and MA are more closely related than those within the $\mathrm{CC}$ region for all three species (Table 6). The asynchronic spawning can determine isolation of populations and therefore the formation of genetically different populations 
TABLE 6. - Spawning period of Lutjanus argentiventris, L. guttatus and L. peru for the three geographic areas: PV, Puerto Vallarta; MA, Manzanillo; and CC, Caleta de Campos. Data for PV and MA from Espino-Barr et al. (2010, 2011) and Gallardo-Cabello et al. (2010) and for CC from Sarabia-Méndez et al. (2010).

\begin{tabular}{|c|c|c|c|c|c|c|c|c|c|c|c|c|}
\hline Species/Months & Jan & Feb & Mar & Apr & May & Jun & Jul & Aug & Sep & Oct & Nov & Dec \\
\hline $\begin{array}{l}\text { L. argentiventris } \\
\text { L. guttatus } \\
\text { L. peru }\end{array}$ & $\begin{array}{c}\text { PV,MA } \\
\text { MA }\end{array}$ & $\begin{array}{c}\mathrm{PV}, \mathrm{MA} \\
\mathrm{CC}\end{array}$ & $\begin{array}{l}\text { MA } \\
\text { PV }\end{array}$ & $\begin{array}{c}\mathrm{CC} \\
\text { PV,MA }\end{array}$ & $\begin{array}{c}\text { MA } \\
\text { PV,MA }\end{array}$ & $\begin{array}{c}\text { PV,MA } \\
\text { MA }\end{array}$ & PV & $\begin{array}{c}\mathrm{PV} \\
\mathrm{CC} \\
\mathrm{PV}, \mathrm{CC}\end{array}$ & $\begin{array}{c}\text { PV,MA } \\
\text { PV } \\
\text { PV }\end{array}$ & $\begin{array}{l}\text { MA } \\
\text { PV }\end{array}$ & $\begin{array}{l}\text { MA } \\
\text { MA }\end{array}$ & $\begin{array}{l}\text { PV } \\
\text { MA } \\
\text { MA }\end{array}$ \\
\hline
\end{tabular}

(Shoji et al. 2005). However, there are no studies on spawning periods of L. argentiventris in CC and results for this geographic area showed here are the results of bi-monthly sample periods.

Range temperature in $\mathrm{CC}$ has been reported to be between $26.7^{\circ} \mathrm{C}$ and $29.2^{\circ} \mathrm{C}$ for spawning of $L$. guttatus (Sarabia-Méndez et al. 2010) and between $27^{\circ} \mathrm{C}$ and $28^{\circ} \mathrm{C}$ for spawning of L. peru (Gallardo-Cabello et al. 2010). Wider temperature preferences for spawning events of $L$. guttatus could explain less dependence on water current temperature, resulting in a smaller amount of discrimination for L. guttatus. However, more information on life history characteristics and studies concerning spawning periods of each species by geographic area in the Central Pacific are needed.

Allometry shows a further source of shape variability that we were able to measure using form (shape plus size). Using shape alone (without size), identification rates are much better than chance and when size was taken into account classification success of L. guttatus was improved by $9.5 \%$, compared with $5.1 \%$ for the other species. This outcome indicates that in large-scale assessment studies of fisheries or when only scales are readily available, good identification of populations is possible irrespective of allometry. This result agrees with the findings of Ibáñez and O'Higgins (2011), who studied the influence of allometry on scale shape and classification. Another source of variability could be the temporal differences in sampling. Time variations of fish scale shape have never been addressed in the literature so we were unable to take this into account in this study. The time lag between the collection periods of the Lutjanus might have confounded geographic variation but further, more intensive sampling will address this issue.

Fish scale shape seems potentially useful in discriminating between populations. The method is nondestructive, allowing rare and endangered species to be returned to the water. It is also quick and less costly than genetic analysis, allowing many individuals from a population/community to be screened quickly potentially for traceability of fish. Results here showed spatial variants within the Lutjanidae but temporal variations should be analyzed in the future for these species and others in order to verify and accurately locate the transition zone influence area within the Pacific coast.

\section{ACKNOWLEDGEMENTS}

This study could not have been done without the help of M. Sarabia-Méndez, E. Cabral-Solís, A.
Garcia-Boa and M. Puente-Gómez, who aided in the sampling and collection of scales, and especially $\mathrm{M}$. Sarabia-Méndez, who digitalized all fish scales. We thank J. Espino-Vela, who kindly reviewed the English version of the manuscript.

\section{REFERENCES}

Allen G.R. 1985. FAO Species catalogue. Snappers of the World. An annotated and illustrated catalogue of lutjanid species known to date. FAO Fisheries Synopsis 6(125): 1-208.

Begg G.A., Waldman, J.R. 1999. An holistic approach to fish stock identification. Fish. Res. 43: 35-44.

Bookstein F.L. 1989. Principal warps: thin-plate splines and the decomposition of deformations. IEEE T. Pattern. Anal. 11: 567-585.

Cowen R.K., Gawarkiewic G., Pineda J., Thorrold S.R., Werner F.E. 2007. Population connectivity in marine systems An overview. Oceanogr. 20: 14-21.

Domínguez-López M., Uribe-Alcocer M., Díaz-Jaimes P. 2010. Phylogeography and historical demography of the Pacific sierra mackerel (Scomberomorus sierra) in the Eastern Pacific. BMC Genetics 11: 1-12.

Dryden I.L., Mardia K.V. 1993. Multivariate shape analysis. Sankya Ser. A 55: 460-480.

Dryden I.L., Mardia K.V. 1998. Statistical shape analysis. John Wiley and Sons, London. $347 \mathrm{pp}$.

Espino-Barr E., Puente-Gómez M., Cabral-Solís E.G., Garcia-Boa A. 2010. Tallas de reproducción de 15 especies de la pesca ribereña en Jalisco. V Foro Científico de Pesca Ribereña, Boca del Río, Veracruz, 7 a 9 de septiembre, $77 \mathrm{pp}$.

Espino-Barr E., Cabral-Solís E.G., Garcia-Boa A., Puente-Gómez M., Miranda-Carrillo M. 2011. La captura de pargos y huachinango en el Pacífico centro, México. Memorias del III Reunión de la Sociedad Mexicana de Pesquerías, Mazatlán, Sinaloa, México, $145 \mathrm{pp}$.

Farias I., Vieira A.R., Gordo L., Figueiredo I. 2009. Otolith shape analysis as a tool for stock discrimination of the black scabbardfish, Aphanopus carbo Lowe, 1839 (Pisces: Trichiuridae), in Portuguese waters. Sci. Mar. 73: 47-53.

Fernández A., Gallegos A., Zavala J. 1992. Carta Oceanográfica física 2, aspectos regionales. Atlas Nacional de México. México, D. F. Instituto de Geografía. National University of México. Vol. II.

Franco-Gordo C., Godínez-Domínguez E., Suarez-Morales E. 2002. Larval fish assemblages in waters off the central Pacific coast of Mexico. J. Plank. Res. 24: 775-784.

Gallardo-Cabello M., Sarabia-Méndez M., Espino-Barr E., Anislado-Tolentino V. 2010. Biological aspects of Lutjanus peru in Bufadero Bay, Michoacán, México: growth, reproduction and condition factors. Rev. Biol. Mar. Oceanogr. 45: 205-215.

Garduño-Paz M.V., Demetriou M., Adams C.E. 2010. Variation in scale shape among alternative sympatric phenotypes of Arctic charr Salvelinus alpinus from two lakes in Scotland. J. Fish Biol. 76: 1491-1497.

Hong-Yi G., Kai W., Wen-Qiao T., Jia-Ming W., Wen-Yin C. 2010. Sibling species discrimination for Chinese genus of Coilia fishes based on sagittal otolith morphology. Acta Zootaxon. Sinica 35: 127-134.

Ibáñez A.L., Lleonart J. 1996. Relative growth and comparative morphometrics of Mugil cephalus L. and M. curema $\mathrm{V}$. in the Gulf of Mexico. Sci. Mar. 60: 361-368.

Ibáñez A.L., Cowx I.G., O'Higgins P. 2007. Geometric morphometric analysis of fish scales for identifying genera, species and 
local populations within the Mugilidae. Can. J. Fish. Aquat. Sci. 64: 1091-1100.

Ibáñez A.L., Cowx I.G., O’Higgins P. 2009. Variation in elasmoid fish scale patterns is informative with regard to taxon and swimming mode. Zool. J. Linn. Soc. 155: 834-844.

Ibáñez A.L., O'Higgins P. 2011. Identifying fish scales: the influence of allometry on scale shape and classification. Fish. Res. 109: 54-60.

Ibáñez A. L., Pacheco-Almanzar E., Cowx I.G. 2012. Does compensatory growth modify fish scale shape? Environ. Biol. Fish. 94: 477-482.

Jarvis R.S., Klodowski H.F., Sheldon S.P. 1978. New method of quantifying scale shape and an application to stock identification in Walleye (Stizostedion vitreum vitreum). T. Am. Fish. Soc. 107: 528-534.

Kent J.T. 1994. The complex Bingham distribution and shape analysis. J.R. Statist. Soc. B 56: 285-299.

Lombarte A., Lleonart J. 1993. Otolith size changes related with body growth, habitat depth and temperature. Environ. Biol. Fish. 37: 297-306.

Marcus L.F., Corti M., Loy A., Naylor G.J.P., Slice D.E. (eds). 1996. Advances in Morphometrics. Nato ASI Series. Vol. 284, Plenum Press, New York, 587 pp.

Mitteroecker P., Gunz P. 2009. Advances in Geometric Morphometrics. Evol. Biol. 36: 235-247

O'Higgins P., Chadfield P., Jones N. 2001. Facial growth and the ontogeny of morphological variation within and between the primates Cebus apella and Cercocebus torquatus. J. Zool. 254: 337-357.

O'Higgins, P., Jones, N. 2007. Morphologika2 v2.5. Hull York Medical School. Available from http://sites.google.com/site/ hymsfme/downloadmorphologica (accessed 10 March 2010).

Palumbi S.R. 2003. Population genetics, demographic connectivity, and the design of marine reserves. Ecol. Appl. 13: 146-158.

Richards R.A., Esteves C. 1997. Use of scale morphology for discriminating wild stocks of Atlantic striped bass. T. Am. Fish. Soc. 126: 919-925.

Rohlf, F.J. 2006. Tps Series. Department of Ecology and Evolution,
State University, N.Y., Stony Brook. Available from http://life. bio.sunysb.edu/morph (accessed 8 July 2010).

SAGARPA. 2010. Anuario estadístico de pesca 2009. Mazatlán, Sinaloa. Comisión Nacional de Acuacultura y Pesca, Secretaría de Agricultura, Ganadería, Desarrollo Rural, Pesca y Alimentación, http://www.conapesca.sagarpa.gob.mx/wb/cona/ anuario_2009_capitulo_i_preliminar

Sale P.F., Van Lavieren H., Ablan Lagman M.C., Atema J., Butler M., Fauvelot C., Hogan J.D., Jones G.P., Lindeman K.C., Paris C.B., Steneck R., Stewart H.L. 2010. Preserving Reef Connectivity: A Handbook for Marine Protected Area Managers. Melbourne, Australia. Connectivity Working Group, Coral Reef Targeted Research and Capacity Building for Management Program, UNU-INWEH.

Sarabia-Méndez M., Gallardo-Cabello M., Espino-Barr E., Anislado-Tolentino V. 2010. Characteristics of population dynamics of Lutjanus guttatus (Pisces: Lutjanidae) in Bufadero Bay, Michoacán, México. Hidrobiológica 20: 149-158.

Shoji J., Tsutomu M., Tanaka M. 2005. Larval growth and mortality of Japanese Spanish mackerel (Scomberomorus niphonius) in the central Seto Inland Sea, Japan. J. Mar. Biol. Ass. U.K. 85: 1255-1261.

Sparre P., Venema S.C. 1995. Introducción a la evaluación de recursos pesqueros Tropicales. Parte 1. Manual. Valparaíso, Chile. FAO Documento Técnico de Pesca.

Swain D.P., Foote C.J. 1999. Stocks and chameleons: the use of phenotypic variation in stock identification. Fish. Res. 43: 113-128.

Waldman J.R. 1999. The importance of comparative studies in stock analysis. Fish. Res. 43: 237-246.

Watkinson D.A., Gillis D.M. 2005. Stock identification of Lake Winnipeg walleye based on Fourier and wavelet description of scale outline signals. Fish. Res. 72: 193-203.

Scient. ed.: E. Macpherson.

Received June 1, 2012. Accepted September 14, 2012.

Published online November 9, 2012. 